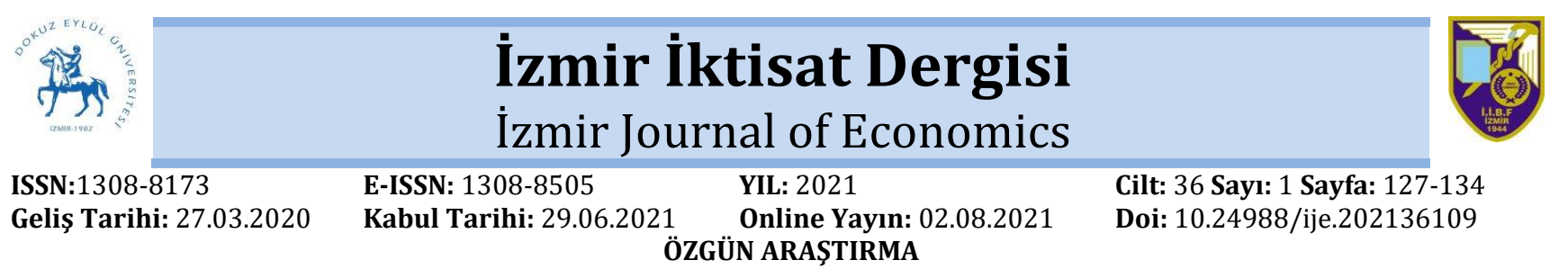

\title{
The Causality Relationship between Foreign Direct Investment and Renewable Energy in G20 and OECD Countries: 2005-20171
}

\author{
Alper Aykut EKİNCİ 2 , Utku ÖLMEZ 3 \\ Abstract
}

This study investigates the link between foreign direct investment (FDI) and renewable energy (RE) as a primary energy source for G20 countries, OECD member countries and Worldwide. For this purpose, bootstrap panel Granger Causality Analysis developed by Konya (2006) was employed for over the period 2005-2017 to examine the existence of causality. The analysis results indicate that there is bidirectional causality between FDI and RE for the G20 and the worldwide. On the other hand, for OECD member countries, there is a one-way causality from RE to FDI. The findings state that foreign direct investments carry the developments that will make renewable energy use widespread, and the use of renewable energy makes the country suitable for foreign direct investment.

Keywords: Foreign Direct Investments, Renewable Energy, Causality

Jel Codes: F21, 013, Q43

\section{G20 ve OECD Ülkelerinde Doğrudan Yabancı Yatırımlar ile Yenilenebilir Enerji Arasındaki Nedensellik İliskisi: 2005-2017 Özet}

Bu çalıșma G20, OECD ve Dünya Geneli için, 2005-2017 dönemi verileri ile panel bootstrap Granger nedensellik testini kullanarak doğrudan yabancı yatırımlar (DYY) ve yenilenebilir enerji (RE) arasındaki ilişsisini analiz etmektedir. Analiz, G20 ve dünya için DYY ve RE arasinda çift yönlü bir nedensellik olduğunu ve OECD için RE 'den DDY'ye tek yönlü bir nedensellik olduğunu göstermektedir. Bulgular, doğrudan yabancı yatırımların yenilenebilir enerji kullanımını yaygınlaştıracak gelişmeleri taşıdığını ve yenilenebilir enerji kullanımının ülkeyi doğrudan yabancı yatırımlara uygun hale getirdiğini belirtmektedir.

Anahtar Kelimeler: Doğrudan Yabancı Yatırımlar, Yenilenebilir Enerji, Nedensellik

Jel Kodlart: F21, 013, Q43

\section{INTRODUCTION}

The acceleration of globalization with the development of technology in recent years has brought countries financially closer to each other. This process has led the capital to move easily and find more profitable countries in a short time.

Foreign direct investments (FDI) contribute positively to the economies of the country, such as transfer of information and technology, contribution to international trade, increasing the competitive characteristics of local enterprises and human capital accumulation (OECD, 2003).

In the literature, it is still a matter of debate whether foreign direct investments prefer countries with the strong economic structure or stabilize the economy of the country they are visiting. Decision makers take into account economic and political criteria in investment decisions. In cases where political reasons

ATIF ÖNERİsí (APA): Ekinci A. A, Ölmez, U. (2021). The Causality Relationship between Foreign Direct Investment and Renewable Energy in G20 and OECD Countries: 2005-2017. İzmir İktisat Dergisi. 36(1). 127-134. Doi: 10.24988/ije.202136109

\footnotetext{
1 This paper was presented at the 2nd International Conference on Technology and Science, November 14-16, 2019.

2 Nevşehir Hacı Bektaș Veli University Faculty of Economics and Administrative Sciences /NEVŞEHİR

EMAIL: alperaykutekinci@gmail.com ORCID: 0000-0002-3141-3380

${ }^{3}$ Nevşehir Hacı Bektaş Veli University Faculty of Economics and Administrative Sciences/NEVŞEHIR

EMAIL: uolmez10@gmail.com ORCID: 0000-0003-0631-8311
} 
come to the fore, it is observed that they try to maintain the balance of interests and put economic reasons in the background. However, if investment is made for economic reasons, the aim is to try to maximize commercial profit (Mencinger, 2003:491-508).

Energy is primarily an indispensable part of human life and is considered essential in social development. Depending on the level of technology development, larger economies of scale are required for economic growth. So, the way to achieve this situation means using more energy. Since the total amount of energy resources is limited, correct use of energy and increasing efficiency are of great importance for ensuring economic development.

Foreign direct investments are expected to make renewable energy use widespread in the host country bringing energy and energy saving technologies. In this way, it is thought to encourage the learning of new techniques, knowledge and production methods. In addition, renewable energy consumption can replace the non-renewable energy type as it protects the environment as a less costly and clean energy type. Alternatively, it can contribute to nonrenewable energy as it can convert waste (Polat, 2018:49).

The main purpose of this study is to examine the causality relationship between foreign direct investments and renewable energy. To reveal this causality, the bootstrap panel Granger causality analysis proposed by Kónya (2006) was applied for 46 cross-sections consist of 43 countries, worldwide, OECD and G20. The analysis has benefited from annual data for the period from 2005 to 2017 with Foreign Direct Investment (FDI) flows as percentage of Gross Domestic Product (GDP) and Renewable Energy as the contribution of renewables to total primary energy supply (TPES) variables.

The rest of the paper is organized as follows. Section 2 covers a review of the literature, and section 3 presents the data and methodology. Section 4 presents empirical findings while section 5 provides a conclusion.

\section{LITERATURE}

Many of the studies in the literature focus on energy consumption and economic growth. Few studies address the relationship between foreign direct investment and energy consumption. Some studies argue that foreign direct investments can save energy and reduce energy consumption, while others argue that FDI will further increase energy consumption in host countries.

Doytch and Narayan (2016) investigated the relationship between sectoral FDI and energy consumption by classifying energy consumption as renewable and non-renewable energy. They concluded that FDI provides energy savings by increasing renewable energy consumption.

Ang (2007) examined the dynamic causal relationship between $\mathrm{CO} 2$ emissions, energy consumption and GDP in France and used a cointegration and vector error correction model (VECM) for the period 1960-2000. As a result, it has been demonstrated that there is a relationship from economic growth to energy consumption and from economic growth to CO2 emissions.

Balasubramanayam et al. (1996) investigated the effect of foreign direct investment on growth in countries with different commercial openness levels in their panel study in 46 developing countries. In countries with an open economy, they stated that the positive impact of foreign direct investments on growth was higher than that of relatively closed economies.

Apergis and Payne (2010) pointed to the existence of a bilateral causality relationship between renewable energy consumption and economic growth in the OECD countries between 1985 and 2005. In addition, Apergis and Payne (2010) in another study found that there is a causal relationship between energy consumption and economic growth in South American countries in the period of 1980-2005.

Öztürk et al. (2010) examined the panel cointegration and causality relationship of 51 lower- and middle-income countries in the 
period of 1971-2005. They concluded that as a result of achieving economic growth in lowincome countries, energy consumption increased while there was a bidirectional causality relationship for middle-income countries.

Lee (2013) examined FDI's contribution to clean energy use, carbon emissions and economic growth in G20 countries for the period 1971-2009. While FDI contributed greatly to economic growth, it also revealed that it increased energy use for G20 countries. It also concluded that FDI is not related to clean energy and therefore does not affect $\mathrm{CO} 2$ emissions in G20 countries.

Hubler (2009) analyzed the impact of FDI and trade on energy saving technology using CGE modeling and concluded that FDI and trade can improve energy saving technology and reduce energy consumption intensity.

Mielnik and Goldemberg (2002) found that energy consumption decreased as FDI per capita increased in the host country. They attributed this reduction in energy intensity to the diffusion effect of FDI through the introduction of new technologies.

Sadorsky (2010) using the dynamic panel data (GMM) model examined the impact of stock market developments and FDI on energy consumption for 22 developing countries. At the end of the study, he concluded a positive relationship between stock market development and energy consumption, but revealed that FDI does not have any effect on energy consumption.

Zeeb et al. (2015) analyzed the impact of FDI on energy saving in 7 South Asian countries between 1990 and 2013 using pooled Ordinary Least Square (OLS), Random Effects (RE) and Fixed Effects (FE) models. They concluded that FDI does not have a significant impact on energy consumption but helps transfer new technologies to this country group.

Paramati, Ummalla and Apergis (2016) studied the effect of FDI on clean energy consumption in 20 emerging countries. The analyzes over
1991-2012 reveal that FDI inflows have a positive impact on clean energy consumption in the long run. Otherwise, in short run there is a unidirectional causality from FDI inflows to clean energy consumption.

Khandker (2018) investigated the relationship between FDI and renewable energy consumption in Bangladesh by employing Johansen co-integration test and the Granger causality test for the period 1980-2015. The analyzes results show that variables are cointegrated in the long run and there is a bidirectional causality relationship from renewable energy consumption to FDI in long run. On the other hand, there is no causal relationship between FDI and renewable energy consumption in the short run.

Ghazouani (2020) examined long run relationship between FDI and renewable energy for seven Middle East and North Africa countries by employing the bootstrap autoregressive distributed lag (ARDL) test for period 1980-2017. Analysis results show that cointegration between FDI inflows, renewable energy consumption, and economic growth in all countries except Iran and Turkey.

Fan and Hao (2020) investigated renewable energy consumption, FDI and gross domestic product nexus in 31 Chinese provinces. The empirical analysis for 2000-2015 indicate existence of a long-term relationship between gross domestic product per capita, FDI per capita, and renewable energy consumption per capita. Furthermore, Granger Causality tests indicate that there are causal relationships from renewable energy consumption to FDI both in the short run and long run.

\section{DATA AND METHODOLOGY}

The analysis of study contains the bootstrap panel Granger causality proposed by Kónya (2006) and a panel with 46 cross-sections. Cross-sections consist of 43 countries, worldwide, OECD and G20. The analysis has benefited from annual data for the period from 2005 to 2017. 


\section{A. A. EKINCİ - U. ÖLMEZ}

The variables are Foreign Direct Investment (FDI) flows as percentage of Gross Domestic Product (GDP) and Renewable Energy as the contribution of renewables to total primary energy supply (TPES). Data were obtained from the OECD Database (October, 2019).

Kónya's (2006) proposal provides several advantages. Firstly, this methodology does not require unit root and co-integration testing of variables. In this way, the variables can be used in their levels. Secondly, the methodology takes into account the presence of contemporary correlations between countries and provides further panel information (equations form a SUR system) and requires one-way, two-way or Granger causality between variables for each country.

The bootstrap panel Granger causality requires the existence of two fundamental assumptions. There are cross-sectional dependence and cross-country heterogeneity.

\subsection{Cross-Sectional Dependence}

A possible cross-sectional dependency problem in a panel analysis often results in inconsistent and upward prediction results (Bai and Kao, 2006:3-30). Therefore, a possible crosssectional dependency is tested before analysis. In the study, the existence of cross-sectional dependence was investigated by Pesaran (2004) procedure. Pesaran (2004), suggests a test for cross-sectional dependence (CD) that can be applied where $\mathrm{N}$ is large, and $\mathrm{T}$ is small.

The CD statistic is calculated as follows:

$$
C D=\sqrt{\frac{2 T}{N(N-1)}}\left(\sum_{i=1}^{N-1} \sum_{J=i+1}^{N}\left(\hat{\rho}_{i j}\right)\right.
$$

In the equation, $N$ is the number of countries, $T$ is the period, and $\rho_{i j}$ is the sample estimation of the double correlation of the error terms.

\subsection{Slope Homogeneity Tests}

Pesaran and Yamagata (2008)' $\tilde{\Delta}$ test for slope homogeneity in large panels is very popular in the literature. The cross-country heterogeneity is investigated by the standardized version of
Swamy's (1970) test for slope homogeneity proposed by Pesaran and Yamagata (2008).

Pesaran and Yamagata (2008) argue that both the F-test and the Swamy test need panel data models where $N$ is relatively small compared to $T$. For this reason, they suggest a standardized version of Swamy's test ( $\tilde{\Delta}$ test) for testing slope homogeneity in large panels. The $\Delta$ test is effective where $(N, T) \rightarrow \infty$ without any restrictions on the relative expansion rates of $N$ and $T$.

Swamy's statistic can then be varied as:

$$
\tilde{S}=\sum_{i=1}^{N}\left(\widehat{\beta}_{i}-\widehat{\beta} w f e\right)^{\prime} \frac{x_{i}^{\prime} M \tau X_{i}}{\widehat{\sigma}_{i}^{2}}\left(\widehat{\beta}_{i}-\widehat{\beta} w f e\right)
$$

where $\widehat{\beta}_{\mathrm{i}}$ is the pooled OLS estimator; $\widehat{\beta}$ wfe is the weighted fixed effect pooled estimator of the Equation 1; M $\tau$ is an identity matrix of order $T$ and $\widehat{\sigma}_{\mathrm{i}}^{2}$ is the estimator of $\sigma_{\mathrm{i}}^{2}$.

Pesaran and Yamagata (2008) then developed the standardized distribution statistic:

$$
\tilde{\Delta}=\sqrt{N}\left(\frac{N^{-1} \tilde{S}-k}{\sqrt{2 k}}\right)
$$

The $\tilde{\Delta}$ test when the error terms are normally distributed has an asymptotic standard normal distribution under the null hypothesis with the condition of $(N, T) \rightarrow \infty$ and so long as $\sqrt{N / T} \rightarrow \infty$.

\subsection{Panel Causality Test}

The panel causality technique proposed by Kónya (2006) requests defining a system which includes two sets of equations.

This approach can be formulated as follows:

$$
\begin{aligned}
& F D I_{1, t}=\alpha_{1,1}+\sum_{i=1}^{k y} \beta_{1,1, i} F D I_{1, t-i}+ \\
& \sum_{i=1}^{k e} \delta_{1,1, i} R E_{1, t-i}+\varepsilon_{1,1, t} \\
& F D I_{2, t}=\alpha_{1,2}+\sum_{i=1}^{k y} \beta_{1,2, i} F D I_{2, t-i}+ \\
& \sum_{i=1}^{k e} \delta_{1,2, i} R E_{2, t-i}+\varepsilon_{1,2, t} . \\
& F D I_{N, t}=\alpha_{1, N}+\sum_{i=1}^{k y} \beta_{1, N, i} F D I_{N, t-i}+ \\
& \sum_{i=1}^{k e} \delta_{1, N, i} R E_{N, t-i}+\varepsilon_{1, N, t}
\end{aligned}
$$


$R E_{1, t}=\alpha_{2,1}+\sum_{i=1}^{k y} \beta_{2,1, i} F D I_{1, t-i}+$

$\sum_{i=1}^{k e} \delta_{2,1, i} R E_{1, t-i}+\varepsilon_{2,1, t}$

$R E_{2, t}=\alpha_{2,2}+\sum_{i=1}^{k y} \beta_{2,2, i} F D I_{2, t-i}+$

$\sum_{i=1}^{k e} \delta_{2,2, i} R E_{2, t-i}+\varepsilon_{2,2, t}$

$R E_{N, t}=\alpha_{2, N}+\sum_{i=1}^{k y} \beta_{2, N, i} F D I_{N, t-i}+$

$\sum_{i=1}^{k e} \delta_{2, N, i} R E_{N, t-i}+\varepsilon_{2, N, t}$

where $F D I$ and $R E$ denote Foreign Direct Investment flows as percentage of Gross Domestic Product (GDP) and Renewable Energy as the contribution of renewables to total primary energy supply (TPES), respectively. $\mathrm{N}$ is the number of countries of the panel $(i=1,2,3, N)$, $\mathrm{t}$ is the time period $(t=$ $1,2,3, \ldots, T)$, and "l" is the lag length. The error terms, $\varepsilon_{1, N, t}$ and $\varepsilon_{2, N, t}$, are supposed to be white noise and may be correlated with each other for a given country.

In equation sets 4 and 5 , for each country ( $i$ ); one-way Granger causality $(X \rightarrow$ $Y$ ) relationship exists when all $\delta_{1, j, i}$ are not zero and all $\beta_{2, j, i}$ are equal to zero. While all $\delta_{1, j, i}$ are zero, all $\beta_{2, j, i}$ are not zero, then there is one-way Granger causality $(Y \rightarrow X)$ relationship. Otherwise, when all $\delta_{1, j, i}$ and $\beta_{2, j, i}$ are not zero, there is a bidirectional Granger causality $(X \leftrightarrow Y)$ relationship and there is no causality relationship if all $\delta_{1, j, i}$ and $\beta_{2, j, i}$ are zero.

\section{EMPIRICAL FINDINGS}

Cross-sectional dependency and slope homogeneity among the countries were tested before panel causality analysis. The outputs of cross-sectional dependence and slop homogeneity tests are presented in Table 1.

The first result shows that the null hypothesis of no cross-sectional dependence across the countries is strongly rejected at the $1 \%$ level of significance. This means that in the countries group there is a cross-sectional dependence, so any shock in one country being transmitted to another one, because of their integrated economies. The second outputs reveal that the null hypothesis of slop homogeneity is strongly rejected. This suggests that, in the countries, a significant economic relationship in one country is not replicated in others. In other words, the direction of panel causality analysis between variables in countries might be heterogeneous and the direction of causal relationships among the variables may differ across countries.

Table 1: Cross-Sectional Dependency and Slope Homogeneity Tests

\begin{tabular}{|c|c|}
\hline \multicolumn{2}{|c|}{ Cross-Section Dependency Test } \\
\hline Statistic & p-Value \\
\hline \multicolumn{2}{|c|}{ CD (Pesaran, 2004) } \\
\hline \multicolumn{2}{|c|}{ FDI } \\
\hline 17.138* & 0.000 \\
\hline \multicolumn{2}{|l|}{$\mathrm{RE}$} \\
\hline $28.253^{*}$ & 0.000 \\
\hline \multicolumn{2}{|c|}{ Slope Homogeneity Tests } \\
\hline Statistic & p-Value \\
\hline \multicolumn{2}{|c|}{ Pesaran and Yamagata (2008) } \\
\hline \multicolumn{2}{|c|}{ Delta } \\
\hline $1.680^{* *}$ & 0.046 \\
\hline Delta Adj & \\
\hline $1.916^{* *}$ & 0.028 \\
\hline
\end{tabular}

Note: $\left({ }^{*}\right)$ and $\left(^{* *}\right)$ shows rejection of the null hypothesis at the $1 \%$ and $5 \%$ level of significance respectively.

As the conditions of the existences of crosssectional dependence and heterogeneity among selected countries are met, the bootstrap panel Granger causality approach can be applied. The results are presented in Table 2.

The findings show that there is a bidirectional causality in case of Belgium, Canada, Chile, France, G20, Germany, Greece, Iceland, Ireland, Lithuania, New Zealand, Poland, Russia, Slovak Republic, Sweden, Turkey, World between Foreign Direct Investment (FDI) and Renewable Energy (RE). On the other hand, there is a one-way causality in case of Austria, Brazil, China, Denmark, Estonia, Finland, Italy, Korea, Latvia, Luxembourg, Mexico, Spain, United States from FDI to RE and from RE to FDI in case of Hungary, India, Japan, Norway, OECD, 


\section{A. A. EKINCI - U. ÖLMEZ}

Portugal, Slovenia. There is no causality for Argentina, Australia, Czech Republic, Indonesia,

Israel, Netherlands, South Africa, Switzerland, United Kingdom.

Table 2: Test Results of Causality between FDI and RE

\begin{tabular}{|c|c|c|}
\hline & $\begin{array}{c}\text { HO: FDI does not Granger causes } \\
\text { RE }\end{array}$ & $\begin{array}{c}\text { HO: RE does not Granger causes } \\
\text { FDI }\end{array}$ \\
\hline Country & Wald Test-stat. & Wald Test-stat. \\
\hline Argentina & 0,700 & 0,187 \\
\hline Australia & 1,709 & 0,963 \\
\hline Austria & $48,544^{*}$ & 2,509 \\
\hline Belgium & $48,336^{*}$ & $8,989 *$ \\
\hline Brazil & $16,747^{*}$ & 0,167 \\
\hline Canada & $38,373^{*}$ & $65,026^{*}$ \\
\hline Chile & $51,905^{*}$ & $11,727^{*}$ \\
\hline China & $42,807^{*}$ & 1,761 \\
\hline Czech Republic & $\begin{array}{r}1,749 \\
1,00\end{array}$ & 0,666 \\
\hline Denmark & $3,218^{* * *}$ & 0,246 \\
\hline Estonia & $23,348^{*}$ & 1,204 \\
\hline Finland & $24,181^{*}$ & 0,966 \\
\hline France & $13,228^{*}$ & $16,032^{*}$ \\
\hline Germany & $11,756^{*}$ & $14,866^{*}$ \\
\hline Greece & $9,997 *$ & $12,577^{*}$ \\
\hline Hungary & 2,668 & $7,533^{*}$ \\
\hline Iceland & $27,976^{*}$ & $101,843^{*}$ \\
\hline India & 0,125 & $11,215^{*}$ \\
\hline Indonesia & 1,457 & 0,896 \\
\hline Ireland & $33,677^{*}$ & $124,171 *$ \\
\hline Israel & 1,968 & 0,244 \\
\hline Italy & $12,893^{*}$ & 0,659 \\
\hline Japan & 0,530 & $2,882^{* * *}$ \\
\hline Korea & $3,126^{* * *}$ & 0,961 \\
\hline Latvia & $2,808^{* * *}$ & 0,149 \\
\hline Lithuania & $61,097^{*}$ & $34,083^{*}$ \\
\hline Luxembourg & $61,910^{*}$ & 2,582 \\
\hline Mexico & $5,937^{* *}$ & 0,254 \\
\hline Netherlands & 0,527 & 0,655 \\
\hline New Zealand & $26,291 *$ & $3,658^{* * *}$ \\
\hline Norway & 0,400 & $35,843^{*}$ \\
\hline Poland & $15,199^{*}$ & $13,989^{*}$ \\
\hline Portugal & 0,806 & $16,653^{*}$ \\
\hline Russia & $6,305^{* *}$ & $156,659 *$ \\
\hline Slovak Republic & $10,926^{*}$ & $15,890^{*}$ \\
\hline Slovenia & 0,107 & $36,007^{*}$ \\
\hline South Africa & 0,807 & 0,645 \\
\hline Spain & $32,195^{*}$ & 1,815 \\
\hline Sweden & $2,850^{* * *}$ & $210,834^{*}$ \\
\hline Switzerland & 1,623 & 0,878 \\
\hline Turkey & $9,753 *$ & $4,548^{* *}$ \\
\hline United Kingdom & 2,528 & 0,149 \\
\hline United States & $8,328^{*}$ & 1,996 \\
\hline WORLD & $8,540^{*}$ & $4,582^{* *}$ \\
\hline G20 & $85,618^{*}$ & $14,190^{*}$ \\
\hline$O E C D$ & 1,717 & $13,997^{*}$ \\
\hline
\end{tabular}

Note: $\left({ }^{*}\right),\left({ }^{* *}\right)$ and $\left({ }^{* * *}\right)$ show rejection of the null hypothesis at the $1 \%, 5 \%$ and $10 \%$ level of significance respectively. 
The summary of the causality results is presented in the Table 3.

Table 3: Direction of Granger Causality Relationship between Countries

\begin{tabular}{c|l}
\hline $\begin{array}{c}\text { Direction of } \\
\text { Granger } \\
\text { Causality }\end{array}$ & \multicolumn{1}{|c}{ Country } \\
\hline \multirow{5}{*}{ FI <-->RE (17) } & $\begin{array}{l}\text { Belgium, Canada, Chile, France, } \\
\text { G20, Germany, Greece, Iceland, } \\
\text { Ireland, Lithuania, New Zealand, } \\
\text { Poland, Russia, Slovak Republic, } \\
\text { Sweden, Turkey, World }\end{array}$ \\
\hline FDI-->RE (13) & $\begin{array}{l}\text { Austria, Brazil, China, Denmark, } \\
\text { Estonia, Finland, Italy, Korea, } \\
\text { Latvia, Luxembourg, Mexico, } \\
\text { Spain, United States }\end{array}$ \\
\hline RE-->FDI (7) & $\begin{array}{l}\text { Hungary, India, Japan, Norway, } \\
\text { OECD, Portugal, Slovenia }\end{array}$ \\
\hline None (9) & $\begin{array}{l}\text { Argentina, Australia, Czech } \\
\text { Republic, Indonesia, Israel, } \\
\text { Netherlands, South Africa, } \\
\text { Switzerland, United Kingdom }\end{array}$ \\
\hline
\end{tabular}

Note: FDI and RE denote foreign direct investment and renewable energy respectively. "-->" stands for direction of causality.

\section{CONCLUSION}

The analysis of the relationship between Foreign Direct Investment (FDI) andRenewable Energy in the OECD countries, by following the bootstrap panel Granger causality, offers intriguing results. These countries are strongly influenced by global developments and shocks and have similar economic characteristics, as part of OECD. Furthermore, any significant economic relationships in one country are not necessarily replicated by the others. The main results of the current study can be concluded as; empirical results show that causality relationship between Foreign Direct Investment and Renewable Energy exists on a large scale.

The findings state that foreign direct investments carry the developments that will make renewable energy use widespread, and the use of renewable energy makes the country suitable for foreign direct investments. These empirical findings can be a guide for foreign direct investment and renewable energy policies. Countries should encourage direct foreign investment inflows and the use of renewable energy sources simultaneously. In addition to the developments brought by foreign direct investments to the countries, the environmental benefit should not be ignored. Likewise, the use of renewable energy technologies should be encouraged and regulations should be implemented more quickly and effectively, in line with both the environmental benefits of using renewable energy and the importance of bringing foreign direct investments to the country.

\section{REFERENCES}

Ang, J. B. (2007). CO2 Emissions, energy consumption, and output in France. Energy Policy, 35(10), 4772-4778.

Apergis, N., Payne J. E. (2010). Energy consumption and economic growth in Central America: Evidence from a panel cointegration and error correction model. Energy Economics, 31, 211 - 216.

Apergis, N., Payne J. E. (2010). Renewable energy consumption and economic growth: Evidence from a panel of OECD. Energy Policy, 38,656- 660.
Balasubramanyam, V. N., Salisu, M., Sapsford, D. (1996). Foreign direct investment and growth in EP and IS countries. The Economic Journal, 106(434), 92-105.

Doytch, N., Narayan, S. (2016). Does FDI influence renewable energy consumption? An analysis of sectoral FDI impact on renewable and non-renewable industrial energy consumption. Energy Economics, 54, 291-301.

Fan, W., Hao, Y., (2020). An empirical research on the relationship amongst renewable energy consumption, economic growth and foreign 


\section{A. A. EKINCI - U. ÖLMEZ}

direct investment in China. Renewable Energy, (146), 598-609.

Ghazouani, T. (2020). Reexamining the foreign direct investment, renewable energy consumption and economic growth nexus: Evidence from a new bootstrap ARDL test for cointegration. Germany: University Library of Munich.

Hubler, M. (2009). Energy saving technology diffusion via FDI and trade: A CGE model of China (No. 1479). Kiel Working Paper.

Khandker, L.L., Amin, S.B., Khan, F. (2018). Renewable energy consumption and foreign direct investment: Reports from Bangladesh. Journal of Accounting, Finance and Economics, 8(3), 72-87.

Kónya, L. (2006). Exports and growth: Granger causality analysis on OECD countries with a panel data approach. Economic Modelling, 23(6), 978-992.

Lee, J. (2013). The contribution of foreign direct investment to clean energy use, carbon emissions and economic growth. Energy Policy, 55, 483-489.

Mencinger, J. (2003). Does foreign direct investment always enhance economic growth? Kyklos, 56(4), 491-508.

Mielnik, O., Goldemberg, J. (2002). Foreign direct investment and decoupling between energy and gross domestic product in developing countries. Energy Policy, 30(2), 8789.

OECD (2019). FDI flows (indicator). Doi: 10.1787/99f6e393-en (Accessed on 13 October 2019)

OECD (2019). Renewable energy (indicator). Doi: 10.1787/aac7c3f1-en (Accessed on 14 October 2019)

OECD (2003). Foreign direct investment statistics, how countries measure FDI 2001.Organization for Economic, Co-operation and Development.

Özturk, I., Acaravcl, A. (2010). The causal relationship between energy consumption and
GDP in Albania, Bulgaria, Hungary and Romania: Evidence from ARDL bound testing approach. Applied Energy, 87(6), 1938-1943.

Paramati, S.R., Ummalla, M., Apergis, N., (2016). The effect of foreign direct investment and stock market growth on clean energy use across a panel of emerging market economies. Energy Economics, (56), 29-41.

Pesaran, M. H. (2004). General Diagnostic Tests for Cross Section Dependence in Panels. IZA Discussion Paper 1240, Germany: Institute of the Study of Labor, Bonn.

Pesaran, M. H., Yamagata, T. (2008). Testing slope homogeneity in large panels. Journal of Econometrics, 142(1), 50-93.

Polat, B. (2018). The influence of FDI on energy consumption in developing and developed countries: A dynamic panel data approach. Journal of Yasar University, 13(49).

Sadorsky, P. (2010). The impact of financial development on energy consumption in emerging economies. Energy Policy, 38(5), 2528-2535.

Swamy, P. A. V. B. (1970). Efficient inference in a random coefficient regression model. Econometrica, 38(2), 311-323.

Zeeb, A., Maqsood, F., Munir, F. (2015). Impact of foreign direct investment on energy saving in South Asian countries. Journal of Asian Development Studies, 4(3), 14-26. 